Jap. J. M. Sc. \& Biol., 15, 249-270, 1962

\title{
STUDIES ON CERCARIAE FROM FRESH WATER SNAILS IN THAILAND
}

\author{
JIRO ITO, \\ Hygiene Laboratory, Shizuoka University, Shizuoka, Japan \\ TONGCHAI PAPASARATHORN AND BANCHONG TONGKOOM \\ Department of Parasitology, Faculty of Public Health, Bangkok, Thailand
}

(Received: September 5th, 1962)

Recent investigations on the human parasite in Thailand revealed that many pathogenic trematodes existed among the inhabitants. Harinasuta et al. (1959) reported heavy endemic areas of Opisthorchis viverrini in the north and north-east parts of Thailand. Sadun and Maiphoom (1953) investigated the prevalence of Fasciolopsis buski among the inhabitants of the central part of Thailand. Vajrasthira et al. (1958, 1959) detected a new endemic area of Paragonimus westermani in Saraburi Province, 90 kilometer far from Bangkok City. One case of human schistosomiasis was reported from the southern part of Thailand and identified as Schistosoma japonicum by Chaiyaporn et al. (1959) though no intermediate snail host was found. Ito et al. (1962) investigated stray dog parasites in Bangkok, resulting in finding several trematode species such as Echinochasmus japonicus, Haplorchis taichui, Haplorchis yokogawai.

Though the faunistic study of cercariae is considered to be an important step in the epidemiological survey of human trematode, no report has been published as yet concerning the cercariae in Thailand.

By the reasons above mentioned, many fresh water snails from various parts of Thailand were collected and brought into the laboratory of Faculty of Public Health in Thailand in order to study the parasitic cercariae in the period from 1960 to 1961. Twelve species of cercariae were detected from four species of snails. In this paper, those cercariae are described, five of which were morphologically identified with known species, and the remaining seven were given new names.

\section{MATERIALS AND METHODS}

Sixteen species of fresh water snails were collected, and twelve of them were examined. These snails, identified by Dr. Kuroda, are illustrated by photographs.

Cercariae and rediae were examined by crushing the snails. When cercariae were obtained, the materials were taken in $0.4 \% \mathrm{NaCl}$-solution and pressed by a cover glass till they became very thin, flat and transparent, so as to be most convenient for morphological observations. These materials could be preserved for the observation of a few hours when the margin of cover glass was sealed with vaseline. The vital staining with 'neutral red or nile blue sulphate was useful sometimes for discrimination of detailed structures. Measurements were taken on materials fixed in $10 \%$ hot formalin, because the results obtained in this way were relatively constant. All drawings were made to scale from such materials.

伊藤二郎（静岡大学教育学部保健学数室） 


\section{GENERAL FeAture}

On the present investigation, four species of snails were detected to be infected with cercariae, namely, Digoniostoma funiculata Walker, Indoplanorbis exustus (Deshayes), Hippeutis umbilicalis (Benson) and Lymnaea (Radix) auricularia rubiginosa Michelin. No cercariae could be found from the other eight species of snails in spite of detailed observations. These are shown in Table 1.

Table 1. Species and localities of snails examined

\begin{tabular}{|c|c|c|c|c|}
\hline Species of snails & Localities collected & $\begin{array}{l}\text { Number } \\
\text { examined }\end{array}$ & $\begin{array}{l}\text { Number } \\
\text { infected }\end{array}$ & $\begin{array}{l}\text { Species of } \\
\text { cercariae }\end{array}$ \\
\hline Viviparus (Taia) ingallsiana & Nomburi, Udon & 409 & 0 & \\
\hline Viviparus filosus & Nomburi, Mahasarakhan & 292 & 0 & \\
\hline Sinotaia polygramma & & 0 & & \\
\hline Sinotaia subciliate & & 0 & & \\
\hline Sinotaia trochoides & Udon & 30 & 0 & \\
\hline Pila (Turbinicola) polita & Mahasarakhan & 134 & 0 & \\
\hline Digoniostoma funiculata & $\begin{array}{l}\text { Mahasarakhan, Udon, } \\
\text { Meanburi }\end{array}$ & 7289 & 214 & 7 spp. of cercariae \\
\hline Wattebledia crosseana & Udon & 120 & 0 & \\
\hline Melanoides tuberculatus & Udon & 9 & 0 & \\
\hline Stenomelania brunnescens & & 0 & & \\
\hline Clea (Anentome) baudoniana & Mahasarakhan & 10 & 0 & \\
\hline $\begin{array}{l}\text { Lymnaea (Radix) auricularia } \\
\text { rubiginosa }\end{array}$ & Mahasarakhan, Bangkok & 210 & 1 & 1 sp. of cercaria \\
\hline Gyraulus convexiusculus & & 0 & & \\
\hline Hippeutis umbilicalis & Bangkok & 200 & 2 & 2 spp. of cercariae \\
\hline Indoplanorbis exustus & Mahasarakhan, Udon & 2005 & 62 & 2 spp. of cercariae \\
\hline Allocimma sp. & Nomburi, Nonthaburi & 1780 & 0 & \\
\hline
\end{tabular}

Among twelve species of cercariae obtained, seven were from Digoniostoma, two from Indoplanorbis and Hippeutis each, and one from Lymnaea. According to the group name these twelve species of cercariae consisted of two Furcocercous cercariae, two Echinostomidae, One Notocotylidae, One Paramphistomidae, one Opisthorchidae, four Xiphidiocercariae and one Cercariaeum. The most abundant species was cercaria of Schistosoma spindale, which is an important pathogenic blood fluke of the water buffalo (Liston and Soparkar, 1918). The next common species was cercaria of Notocotylus attenuatus which may be pathogenic for the domestic duck and the fowl. The cercaria of Opisthorchis viverrini, a famous human liver fluke, was also rather common in Digoniostoma funiculata. These are shown in Table 2 with other rarely occurring cercariae.

The description of each cercariae is as follows.

1. Cercaria of Schistosoma spindale (Montgomery, 1906)

In November and December, 1960, many living specimens of snails, Indoplanorbis exustus (Deshayes) were brought into the laboratory from Udon and Mahasarakhan 
Table 2. A list of hosts, locarities and infection rates of each cercariae

\begin{tabular}{|c|c|c|c|}
\hline Species of Cercariae & Host & Locality & Infection rate \\
\hline $\begin{array}{l}\text { Cercaria of Schistosoma } \\
\text { spindale }\end{array}$ & Indoplanorbis exustus & $\begin{array}{l}\text { Udon, } \\
\text { Mahasarakhan }\end{array}$ & $3.10 \%(62 / 2005)$ \\
\hline Cercaria dorsoptera n. sp. & Hippeutis umbilicalis & Bangkok & $0.50 \% \quad(1 / 200)$ \\
\hline $\begin{array}{l}\text { Cercaria of Echinostoma } \\
\text { revolutum }\end{array}$ & Lymnaea auricularia & Bangkok & $0.50 \% \quad(1 / 200)$ \\
\hline $\begin{array}{l}\text { Cercaria of Echinochasmus } \\
\text { japonicus }\end{array}$ & Digoniostoma funiculata & Mahasarakhan & $0.25 \% \quad(2 / 800)$ \\
\hline $\begin{array}{l}\text { Cercaria of Notocotylus } \\
\text { attenuatus }\end{array}$ & Digoniostoma funiculata & $\begin{array}{l}\text { Mahasarakhan, } \\
\text { Udon }\end{array}$ & $1.77 \%(129 / 7289)$ \\
\hline Cercaria udonensis $\mathrm{n}$. sp. & Indoplanorbis exustus & Udon & $0.33 \% \quad(1 / 300)$ \\
\hline $\begin{array}{l}\text { Cercaria of Opisthorchis } \\
\text { viverrini }\end{array}$ & Digoniostoma funiculata & $\begin{array}{l}\text { Udon, Mahasara- } \\
\text { khan, Meanburi }\end{array}$ & $0.18 \%(13 / 7289)$ \\
\hline $\begin{array}{l}\text { Cercaria digoniostomae } \\
\text { n. sp. }\end{array}$ & Digoniostoma funiculata & $\begin{array}{l}\text { Udon, } \\
\text { Mahasarakhan }\end{array}$ & $0.74 \%(54 / 7289)$ \\
\hline Cercaria krungteb $\mathrm{n} . \mathrm{sp}$. & Hippeutis umbilicalis & Bangkok & $(1 / 200)$ \\
\hline Cercaria siamensis $\mathrm{n} . \mathrm{sp}$. & Digoniostoma funiculata & $\begin{array}{l}\text { Udon, } \\
\text { Mahasarakhan }\end{array}$ & $0.11 \% \quad(8 / 7289)$ \\
\hline Cercaria setsu n. sp. & Digoniostoma funiculata & Mahasarakhan & $(7 / 7289)$ \\
\hline $\begin{array}{l}\text { Cercariaeum magnasoma } \\
\text { n. sp. }\end{array}$ & Digoniostoma funiculata & Udon & $(1 / 7289)$ \\
\hline
\end{tabular}

Provinces, the north-east of Thailand. Cercarial examination of these snails revealed that 62 out of 2005 , or $3.1 \%$ of snails were found to be infected with one kind of schistosome cercariae. The general structure was as follows.

Morphology: This cercaria has a typical character of the genus Schistosoma. The measurements of specimens fixed with $10 \%$ hot formalin indicated the following results ; body, 147-158 (av. 150) $\mu$ long by 50-64 (av. 55) $\mu$ wide; tail stem, 125-250 (av. 200) $\mu$ long by $28-32$ (av. 30) $\mu$ wide; tail furcae, $64-86 \mu$ long by $18 \mu$ wide. The body surface, as well as the tail surface, is covered with many sharp backward pointing spines, while particularly larger spines are found on the ventral part of the anterior extremity around the mouth opening. Five pairs of hollow piercing spines are located at the anterior end of the body corresponding to the openings of the penetrating gland duscts. The anterior part of the body is occupied with a well developed protrusidle anterior organ. in which the cephalic glands are faintly observed. The ventral sucker is a strong muscular structure situating on threefourths of the body distance from the anterior end. The mouth is subterminal and leads back into the anterior organ. An esophagus is extended to the middle part of the body where it ends in blind with a small dumb-bell shaped swelling. Five pairs of large penetrating gland cells occupy the posterior part of the body. These gland cells are composed of two groups, the anterior two pairs of coarsely granulated glands and the posterior three pairs of finely granulated ones. Five pairs of ducts arise from each gland. running forwards, and open into five pairs of hollow piercing spines at the anterior tip of body.

A thin walled small excretory bladder is located at the posterior part of the body. One pair of main collecting tubes arises from the antero-lateral corner of the bladder and runs forwards in a zigzag course, then divides into an anterior and a posterior collecting tube in front of the acetabulum. The anterior collecting tube runs forwards 


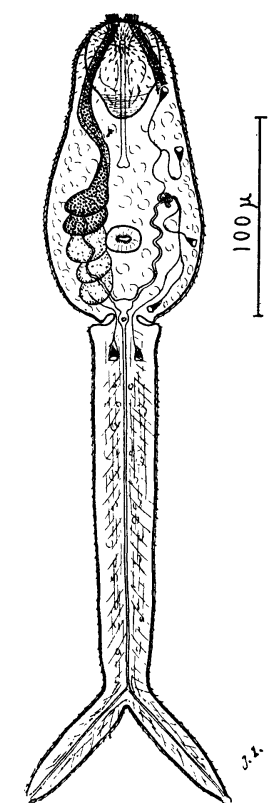

Fig. 1. Cercaria of Schistosoma spindale (Montgomery, 1906).

receiving two flame cells, and the posterior collecting tube runs backwards getting two flame cells on this way within the body, then enters into the tail and terminates in one flame cell near the proximal end of the tail stem. So the flame cell formula of this cercaria is demonstrated as $2[(1+1)+(1+1+[1])]=10$. A caudal excretory tube arises from the posterior end of the bladder, and after passing backwards to the distal end of the tail furcae, it opens at the end of furcal ramus through a cup shaped hole respectively. An Island of Cort is observed at the point where the caudal excretory tube joins the bladder.

The tail and the furci are only larval appendages and their morphology is comparatively simple. The furcal rami are distinctly constricted off from the tail stem. The excretory duct runs throughout the length of the tail and the furcal rami.

Experimental infection: Mice, guinea pigs, rabbits and goats were subjected to this cercarial infection. Six or ten weeks after infection, these animals were autopsied and the portal and mesenteric vessels were examined in order to get schistosome adults. Many worms were found from most of these animals, but the majority of the worms obtained were young males. After several times of experimental infections a few female worms with the characteristic ova of $S$. spindale could be collected. The detailed data will be reported later.

Discussion: Above mentioned morphology and experimental infection of this cercaria agrees entirely with the cercaria of Schistosoma spindale reported by Soparkar (1921), who found it in the district near Bombay in India. He reported it also from the same species of snail, Planorbis exustus, as we did. Moreover the present results of experimental infection are very similar to that of Liston and Soparkar (1918) who experienced also the frequent occurrence of young male worms only.

So, this is the first report that Schistosoma spindale is distributed not only in India 
but also in Thailand. A more detailed information concerning this blocd fluke will be published in the future.

Yokogawa (1961) detected also the high infection of this cercaria in Indoplanorbis exustus from the north-east of Thailand. Furthermore he reported that there were many people who were suffering from the dermatitis presumably caused by this cercaria.

\section{Cercaria dorsoptera n. sp.}

Host: Hippeutis umbilicalis (Benson).

Locality: Bangkok, Thailand.

Specific diagnosis: Furcocercous cercaria of Spirorchis type. The cercaria is poorly developed and a weak swimmer. The body and tail are covered with minute spines. The dorso-median surface of the body is beset with a membraneous fin-fold. The protrusible anterior organ is slightly muscular within which a mouth and an esophagus are observed faintly. Delicate bristles are sometimes apparent in regular circlets around the mouth opening and the cone of the anterior organ. No pharynx

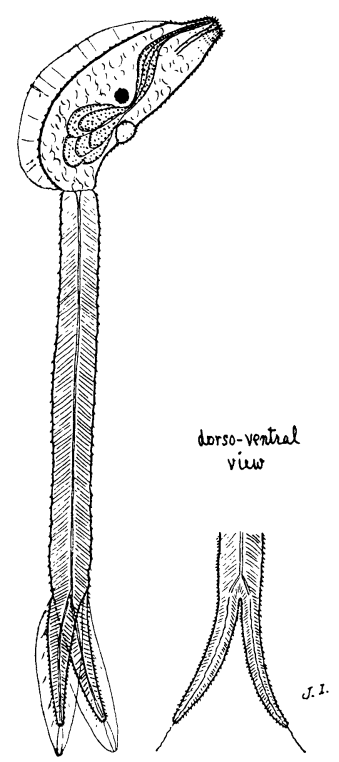

Fig. 2. Cercaria dorsoptera n. sp.

is present. Several pairs of penetrating gland cells send their ducts forwards and open at the anterior top of the body. One pair of pigmented eye spots is prominent at the middle of the body. Acetabulum situated on the ventral side of the body is rudimentary and is projected moderately being covered with minute spines. At the posterior end of the body is a small globular excretory bladder. Flame cells are indistinct.

The tail is rather muscular and well developed. The tail stem is much longer than the furcal rami which are provided with a fin fold on their dorso-ventral surface, respectively. The caudal excretory tube runs backwards throughout the tail stem and furcae, and opens at the distal end of each ramus. 
This cercaria was observed in Hippeutis umbilicalis from Bangkok, its infection rate being one out of 200 , or $0.5 \%$. Though our observation is rather insufficient, it has much resemblance to Cercaria Indicae IX reported by Sewell (1922). But there are some differences between these cercariae in such points as the snail host and locality. So a new name, Cercaria dorsoptera n. sp. was given to the present species. This cercaria is closely related to that of Spirorchis elephantis or Spirorchis parvus investigated by Wall (1941). This indicates that the present cercaria may penetrate into some fresh water turtles to develop in their blood vessel.

\section{Cercaria of Echinostoma revolutum (Froelich, 1802)}

This cercaria was observed once out of 200 specimens of [Lymnaea (Radix) auricularia rubiginosa in Bangkok. The morphology was as follows.

The cercarial body is comparatively large, and the tail is slender and slightly longer than the body. Several pairs of sensory hairs are on the anterior margin of the body. Thirty-seven collar spines are arranged in a double alternate and uninterrupted row. Four pairs of them on each ventral side are larger than the remaining spines, forming end groups. Two suckers are well developed. The ventral one, being on well behind

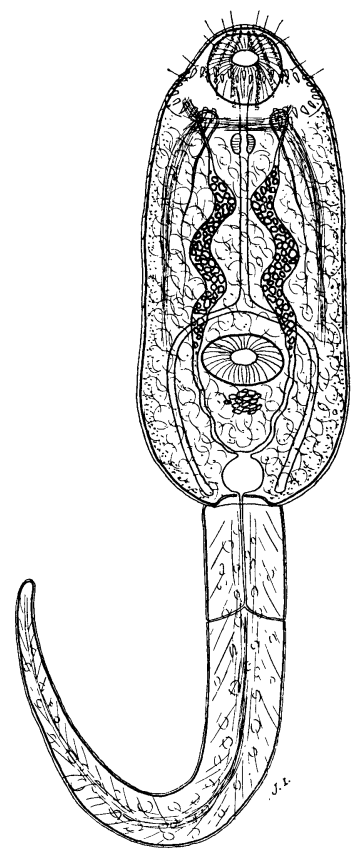

Fig. 3. Cercaria of Echinostoma revolutum (Froelich, 1802).

the middle of the body, is slightly larger than the oral one. A mouth opening leads back into a short prepharynx and a long esophagus through a muscular pharynx. The esophagus divides into two long caeca in front of the acetabulum and ends in blind at the posterior part of the body. Cystogenous gland cells are distributed throughout the body, obscuring other internal organs. Three rudimentary pairs of ducts, perhaps from the penetrating glands are faintly recognized around the oral sucker. A thin 
walled excretory bladder is situated at the posterior part of the body. One pair of collecting tubes are derived from the antero-median part of the bladder, and runs forwards in a zigzag course through each side of the ventral sucker and the esophagus, then turns back forming a loop at the level between the oral sucker and the pharynx. Fourty or fifty excretory concretions are compacted in the swelling part of both the collecting tubes. These concretions are strongly refractable and prominent. Flame cells are missed to observe. A nervous commissure across the prepharynx and nerve fibers on each side of the body is well observed.

Though it lacks the experimental proof, this cercaria is identifiable as the cercaria of Echinostoma revolutum, as far as its morphology, especially the number of collar spines, is concerned. Several encysted metacercariae from the same snail host confirm this identification, too. Many literature show that the first intermediate snail host of this trematode in the oriental region is Lymnaea spp. without any mention on the present host, Lymnaea (Radix) auricularia rubiginosa Michelin (syn. Lymnaea siamensis) from Thailand. So this is the first report on Echinostoma revolutum from Thailand.

\section{Cercaria of Echinochasmus japonicus Tanabe, 1926}

This cercaria was detected from 2 out of 800 specimens of Digoniostoma funiculata in Mahasarakhan Province. The morphology was as follows.

Middle sized echinostome cercaria. The body is oval and the tail is slender in shape. No spine on the surface of the body or the tail, but four pairs of sensory hairs on the body surface as shown in Fig. 4. A well developed oral and ventral sucker is of a nearly equal size. Around the opening of the oral sucker, approximately 20 small denticulated spines are arranged in one row. The same spines, whose number being nearly 40, are recognized also around the opening of the ventral sucker. The alimentary canal is composed of a mouth, a short prepharynx, a well defined pharynx, a long esophagus and two caeca terminating in blind at the posterior end of the body. Seven pairs of penetrating gland cells are faintly recognized on both sides of the esophagus. Their ducts run forwards, making three groups of duct bundles, and open at the tip of the body. Numerous cystogenous gland cells are compacted within the body. A thin walled excretory bladder is located at the posterior part of the body. One pair of main collecting tubes arise from the bladder through a median short stem, and runs forwards in a zigzag course. These tubes are much prominent because of their wide size and a few refractable excretory concretions contained in them. Behind the oral sucker, these main collecting tubes make a loop and turn back, then run backwards reaching both the sides of the ventral sucker, where they divides again into an anterior and a posterior collecting tubes. Each of them receives four flame cells, so the flame cell formula is represented as $2[(2+2)+$ $(2+2)]=16$.

This cercaria is just similar morphologically to that of Echinochasmus japonicus reported by Yamaguti (1951). Though no experimental infection was performed on the life cycle of this cercaria, it is identifiable as the cercaria of Echinochasmus japonicus In fact, the adult fluke of this species had been discovered from stray dogs in Bangkok, their infection rate being $5.5 \%$ (Ito et al., 1962). So this fluke is considered to be rather common in Thailand. According to Yamaguti (1951), this cercaria was detected from Bulimus manchouricus japonicus, closely related species to Digoniostoma funi- 


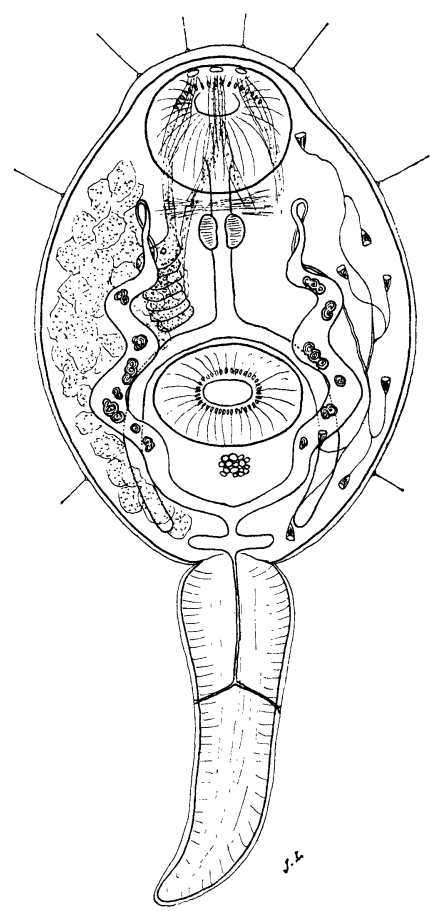

Fig. 4. Cercaria of Echinochasmus japonicus (Tanabe, 1926)

culata in Thailand. The second intermediate host was proved also by him to be a fresh water fish, Pseudorasbora parva, and a tadpole of Rana rugosa. This scheme of the life cycle may be nearly the same in Thailand as in Japan.

\section{Cercaria of Notocotylus attenuatus (Rudolphi, 1809)}

This cercaria was most abundant in Digoniostoma funiculata from Mahasarakhan and Udon Provinces. Out of 7289 snails, 129 or $1.8 \%$ of snails were infected with this cercaria.

The cercaria is a typical monostome type. The body measures $297-322 \mu$ in length and $150-179 \mu$ in width. The body surface is provided with no spine but five pairs of sensory hairs located at its anterior part. The postero-lateral margin of the body is modified as one pair of corner pockets which may serve as an adhesive organ when the cercaria creeps. The body is strongly opaque due to the densely compactad cystogenous materials in the whole space of the body cavity except the anterior part. At the antero-ventral end of the body is a mouth opening which is surrounded by a well developed oral sucker, $39-50 \mu$ in diameter. A pair of long caeca is connected to the mouth by a short prepharynx. Three prominent eye spots are situated at the anterior part of the body.

An anepithelial small excretory bladder is located at the median posterior end of the body. A pair of main collecting tubes from the bladder runs forwards along the caeca to a little behind the lateral eye spots, and joins each other at the median part of the body where the prepharynx bifurcates. These collecting tubes are compacted with many small refractile excretory concretions. A secondary collecting tube from 


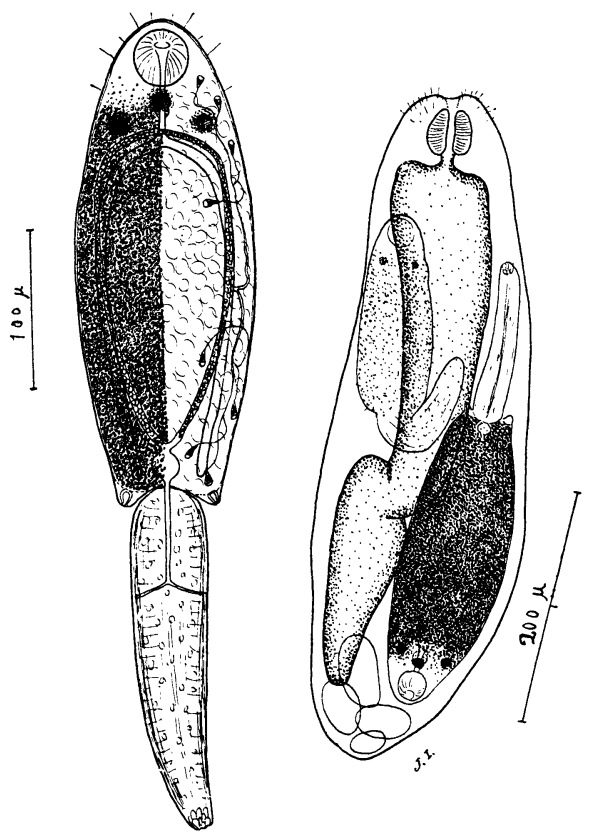

Fig. 5. Cercaria and redia of Notocotylus attenuatus (Rudolphi, 1809).

the middle part of each main tube divides in a short distance into an anterior and a posterior collecting tube, which receive four flame cells grouping in two, respectively. Thus, the flame cell formula is represented as $2[(2+2)+(2+2)]=16$.

A tail measures $0.18-0.22 \mathrm{~mm}$ in length and $0.05-0.08 \mathrm{~mm}$ in width. It is connected with a deep groove to the posterior ventral end of the body, though it is easily detachable from the body. A caudal excretory tube runs backwards from the excretory bladder and divides at the middle part of the tail.

The parthenita is slender and cylindrical rediae which are yellowish in color without any foot appendix. Matured rediae fixed by $10 \%$ hot formalin measure $0.53-0.68$ $\mathrm{mm}$ in lengh and $0.19-0.22 \mathrm{~mm}$ in width. The anterior part of the body surface is beset with many minute sensory hairs. The muscular spheroid pharynx, 47-90 $\times 39-80 \mu$ in size, is followed by a large intestine. A few matured cercariae are contained in a redia together with several germ balls.

As far as the above mentioned description shows, here is no noticeable difference between the present cercaria and that of Notocotylus attenuatus reported by Yamaguti (1938). Moreover, the first intermediate snail host is Digoniostoma funiculata in the former, and Bulimus manchouricus japonicus in the latter, both snails being very similar belonging to Bulimidae. So the present cercaria is identified as that of Notocotylus attenuatus, though no proof on its life cycle is demonstrated.

\section{Cercaria udonensis n. sp.}

Host: Indoplanorbis exustus (Deshayes)

Locality: Udon, Thailand

Specific diagnosis: Cercaria belonging to Paramphistomidae. The body is oval in shape, being more blunt in the pasterior part. It measures $0.27 \mathrm{~mm}$ in length and 
$0.18 \mathrm{~mm}$ in width. The body is strikingly opaque due to the densely compacted lodlike cystogenous materials, each of which measures $11 \times 4 \mu$. An oral sucker, $100 \times$ $82 \mu$ in size, is situated at the anterior part of the body. A mouth opening is followed by a short prepharynx which is divided into two caeca reaching the posterior fourth of the body. Pharynx is lacking. One pair of prominent eye spots situated at both the sides of the prepharynx. A well developed large ventral sucker, $183 \times 158 \mu$ in size, is located at the posterior part of the body on its ventral side. No particular swelling of the excretory bladder is observed. Immediately in front of the ventral sucker, two collecting tubes are arisen, run forwards giving off an another collecting tube in the way, and join each other at the middle part of the body with a short median project. The above mentioned side branch on each side runs outerwards reaching behind the eye spots where it bifurcates again and terminates in a short

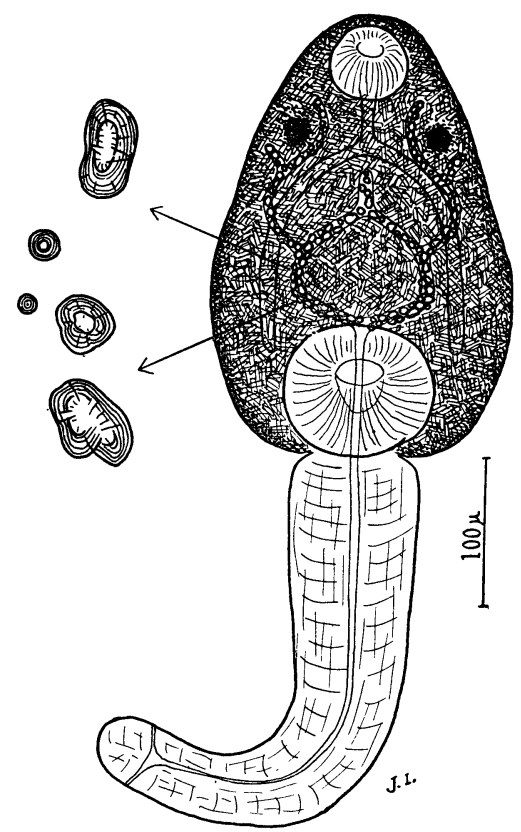

Fig. 6. Cercaria udonensis n. sp.

distance. These collecting tubes are compacted with many small and large excretory concretions, the largest one of which measures $22 \times 18 \mu$ in size. They are strongly refractable and marked with a few radial striations and many concentric circled striations. The further detailed excretory system could not be clarified.

A comparatively large tail is smooth on its surface. A caudal excretory tube derived from the front of the ventral sucker runs backwards, and after dividing in front of the terminal end of tail, they open on both lateral sides.

This cercaria was obtained once from 300 specimens of Indoplanorbis exustus in Udon Province. Its structure strongly resembles the cercaria of Paramphistomum cervi reported by Szidat (1936) and Takahashi (1927), but differs from it in the dimension of oral and ventral and ventral suckers. The present cercaria has much larger suckers than that of Paramphistomum cervi. So it is hesitated to identify as P. cervi, and a 
new name, Cercaria udonensis is proposed for this ceacaria.

\section{Cercaria of Opisthorchis viverrini (Poirier, 1886)}

One species of parapleurolophocercous cercaria was occasionally found from Digoniostoma funiculata in the north-east of Thailand, where is the heavy endemic area of liver flukes among the inhabitants. Its infection rate was 5 out of 1800 , or $0.28 \%$ in Mahasarakhan, 5 out of 400 , or $1.25 \%$ in Udon, 3 out of 31 , or $10 \%$ in Meanburi, etc.

The cercaria closely resembles that of Clonorchis sinensis. The body surface is covered with many minute spines and beset also with seven pairs of sensory hairs, among which three pairs are on the anterior part and four pairs are on the lateral side of the body. An oral sucker is well developed but a ventral sucker is faintly

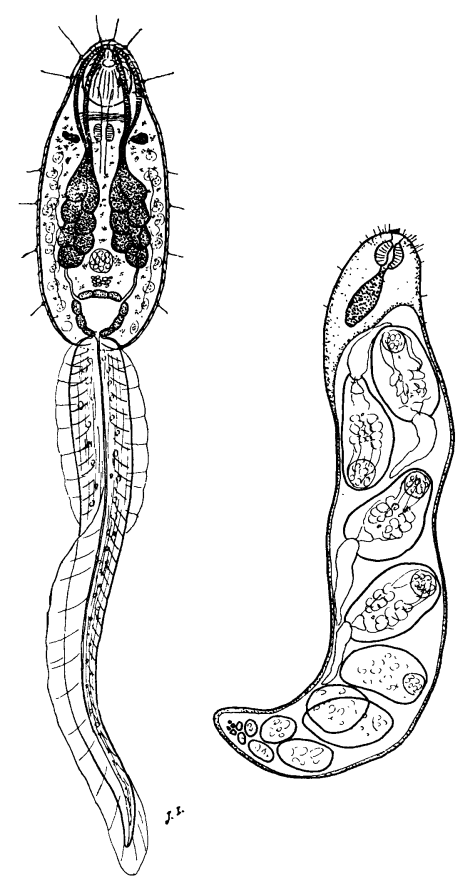

Fig. 7. Cercaria and redia of Opisthorchis viverrini (Poirier, 1886).

recognized. A pharynx is observed between the eye spots, but the intestinal caeca is not differentiated yet. Seven pairs of penetrating gland cells are prominent and their ducts run forwards grouping in two pairs and open at the proximal end of the body. An epithelial excretory bladder is located at the posterior end of the body. Two main collecting tubes start from the antero-lateral corner of the bladder and divide into the anterior and posterior collecting tubes at the middle part of the body. Though further details of the excretory system could not be clarified at the time, the flame cell formula is, according to Vajrasthira et al. (1961) who investigated the metacercaria of $O$. viverrini, presumably represented by $2[(3+3)+(3+3+3)]=30$.

A well developed slender tail is longer than the body. It is provided with lateral fin folds on the lateral surface of one third length of proximal part, and a dorso- 
ventral fin fold on the posterior two thirds of the tail. A caudal excretory tube runs along the center of the tail.

The redia is sausage shaped without any foot appendix. On the anterior surface of the body many sensory hairs are observed. Several young cercariae and germ balls are contained in it.

By the reasons that this cercaria is the only species belonging to parapleurolophocercaria in this endemic area of liver flukes, and that the present snail host is closely related to Bulimus spp., a known intermediate host of Opisthorchis felineus and Clonorchis sinensis, this cercaria was morphologically identified as that of Opisthorchis riverrini, though it lacks any experimental proof now. Standing on the identification of this cercaria and the supposition of flame cell formula, comparisons of three cercariae of liver fluke, $C$. sinensis, $O$. felineus and $O$. viverrini, reveal some differences among them. Concerning the excretory pattern, $C$. sinensis has a formula of $2[(3+3)+(3+$ $3+3)$ ], according to Komiya and Tajimi (1940), in O. felineus the pattern is, according to them also, $2[(5+5)+(5+5+5)]$, whereas that of $O$. viverrini seems to be $2[(3+3)$ $+(3+3+3)]$, the same as that of $C$. sinensis. The lateral fin folds on the anterior one third of the tail is also valuable to distinguish them, namely, it is the widest in $O$. viverrini, moderate in $C$. sinensis and just rudimentary in O. felineus. Further differentiations may be shown in the number and position of sensory hairs, etc. Although Yamaguti (1958) in his text book considered $O$. viverrini is a synonym of $O$. felineus, these two species are apparently different even according to the above mentioned reasons.

\section{Cercaria digoniostomae $\mathrm{n}$. sp.}

Host: Digoniostoma funiculata Walker.

Locality: Udon and Mahasarakhan, Thailand.

Specific diagnosis: A xiphidiocercaria belonging to Microcotyle group of Sewell (1922). The body is small ellipsoidal in shape, being covered with many minute spines and beset with four pairs of sensory hairs. The body length is $86-107 \mu$ and its width is $64-72 \mu$. A well developed oral sucker measures $18-28 \mu$ in length by $28-32 \mu$ in width. A ventral sucker situating on one third posterior of the body, is smaller than the oral sucker, measuring $14-21 \mu$ in diameter. A stylet is prominent and has a shoulder on its solid part, but is slender lancet shape in immature cercariae. Their sizes are $10 \times 3 \mu$ in an immature case and $14 \times 4 \mu$ in a mature one. The inner side of the mouth opening is covered with a thick cuticle which is easily stainable by neutral red, looking like the virgulate substance. The prepharynx is very short being followed with a pharynx of $10 \times 14 \mu$ in size. No intestinal caeca is observed. Three pairs of penetrating gland cells are found on the middle part of the body. Their ducts run forwards around the oral sucker, and open at the anterior end of the body. Their contents are rather homologous. The excretory bladder is a typical $\mathrm{Y}$ in shape. Flame cell formula is represented by $2[(2+2+2)+(2+2)]=20$. The tail is slender and covered with many minute spines also. It measures $39-64 \mu$ by $25-28 \mu$.

Parthenita is a sporocyst measuring $129-516 \mu$ in length and $90-116 \mu$ in width. Usually less than 10 mature cercariae are contained in a developed sporocyst.

This cercaria is rather common in Digoniostoma funiculata. Totally 54 out of 7289 snails, or $0.74 \%$ of snails, harboured them. Sometimes many encysted metacercariae were found side by side within the same snail host. These cysts measure 1C0- 
$125 \mu$ in diameter. Several experimental infections of this cyst to mice failed to obtain the adult fluke, but it belongs apparently to the group of Plagiorchioidea Dollfus, 1930. Herewith a new name, Cercaria digoniostomae, is given to the present cercariae.
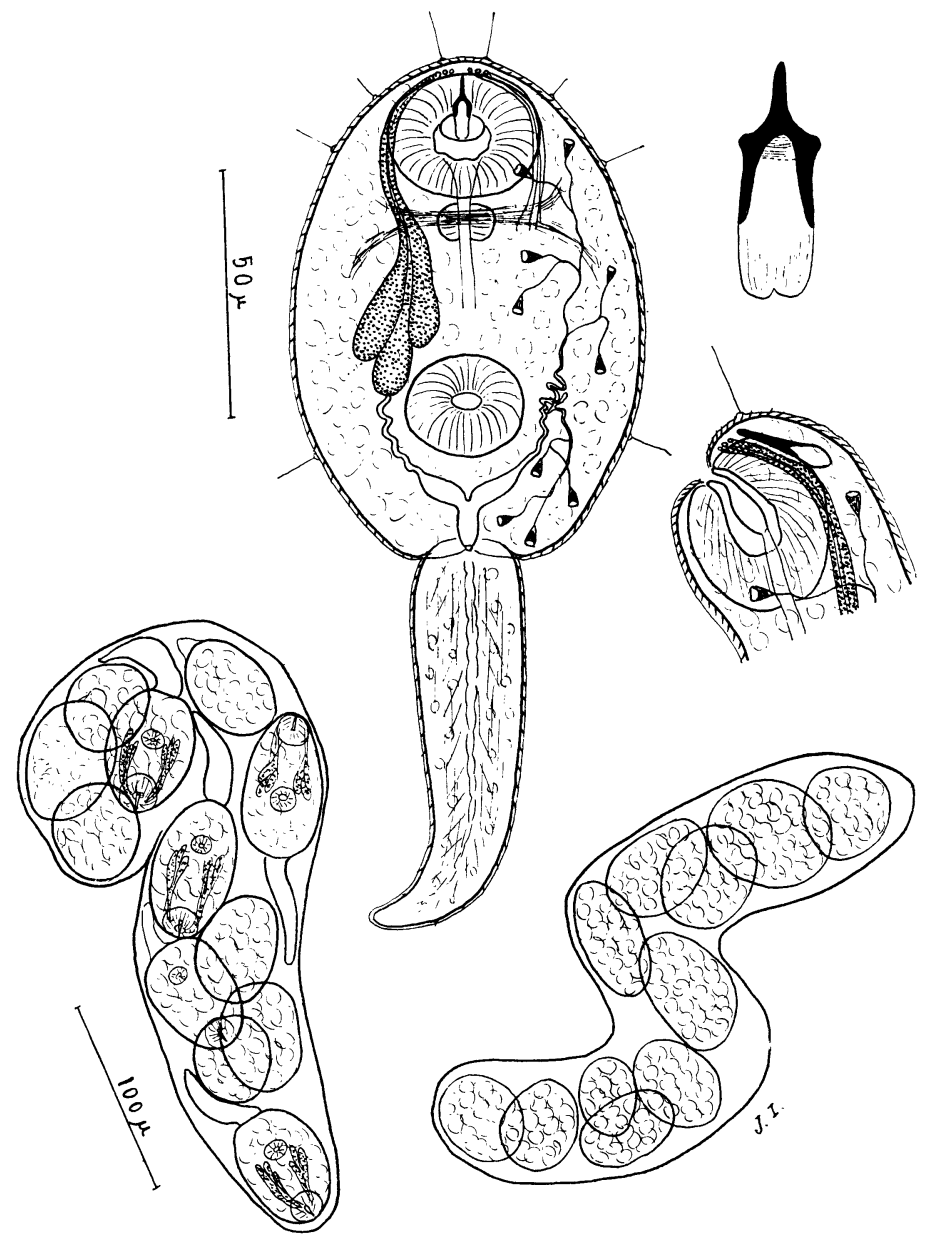

Fig. 8. Cercaria digoniostomae n. sp.

\section{Cercaria krungteb n. sp.}

Host: Hippeutis umbilicalis (Benson).

Locality: Bangkok, Thailand.

Specific diagnosis: Xiphidiocercaria belonging to the Microcotyle group of Sewell (1922). The body is oval in snape, measuring $119-136 \mu$ in length and $67-106 \mu$ in width. It is covered with many minute spines on its surface, and is beset with four pairs of sensory hairs on the anterior part of the body surface. A well developed oral sucker measures $33-41 \mu$ in diameter. A conspicuous stylet is elongated rhombic in shape. The alimentary canal consisted of a mouth opening, a long prepharynx, a small pharynx, a short esophagus and two rhabdocoel caeca terminating in front of 
the acetabulum. The acetabulum is smaller than the orau sucker, measuring $28-30 \mu$ in diameter and being situated at a slightly posterior part of the body. A large cup shaped excretory bladder occupies the posterior space of the budy. Two collecting tubes are of a mesostome type. The flame cell pattern could not be determined, though only three pairs of them are observed.

The tail is slender and rather short. It measures $61-90 \mu$ in length and $20-24 \mu$ in width.

This cercaria was found once from 200 specimens of Hippeutis umbilicalis at Bangkok. Now a new name, Cercaria krungteb n. sp, is propsed to be given to this cercaria, the meaning of "Krungteb" in Siamese being Bangkok, the capital of Thailand.

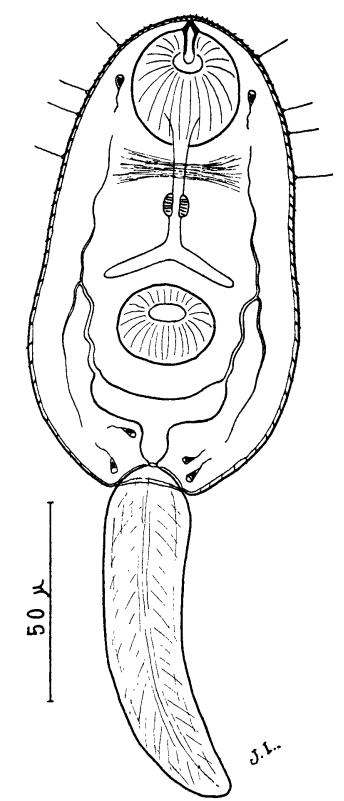

Fig. 9. Cercaria krungteb n. sp.

\section{Cercaria siamensis n. $\mathrm{np}$.}

Host: Digoniostoma funiculata Walker.

Locality: Udon. Mahasarakhan, Thailand.

Specific diagnosis: A xiphidiocercaria belonging to the Virgula group of Lühe 1909). The body is ellipsoidal in shape, bearing many minute spines and six pairs of sensory hairs on the surface of the body. It measures $121 \mu$ in length and $81 \mu$ in width. A well developed oral sucker, measuring $33 \mu$ by $36 \mu$ has a small but typical virgula organ within it. A comparatively small stylet on a mouth opening is $14 \mu$ in length and $5 \mu$ in width. A pharynx of $10 \times 14 \mu$ in size follows a prepharynx. No intestinal caeca are differentiated yet. Four pairs of penetrating gland cells are located around the ventral sucker. Among them, two anterior cells contain the finely granulated materials, and the other two posterior cells contain the coarsely granulated ma- 
terials. The ducts of these cells run forwards and open at the anterior extremity of the body. A ventral sucker of $21 \times 24 \mu$ in size is smaller than the oral sucker, and is situated at two thirds posterior of the body. A mass of genital primordium is observed just behind the ventral sucker. A cup shaped excretory bladder is found on the posterior part of the body. Main collecting tubes are of a mesostome type. The flame cell pattern could not be clarified. The tail is slender and shorter than the body length. It has a strong power of extension and contraction. Neither a spine nor a fin fold is provided on the tail.

Totally 8 out of 7289 specimens of Digoniostoma funiculata harbored this cercaria. In some place 6 out of 158 specimens, or $3.8 \%$, are parasitized with this cercaria. This may develop to the member of Lecithodendriidae or some related ones. Though no life cycle is known at present, a new name, Cercaria siamensis $\mathrm{n}$. $\mathrm{sp}$. is given to the present cercaria.

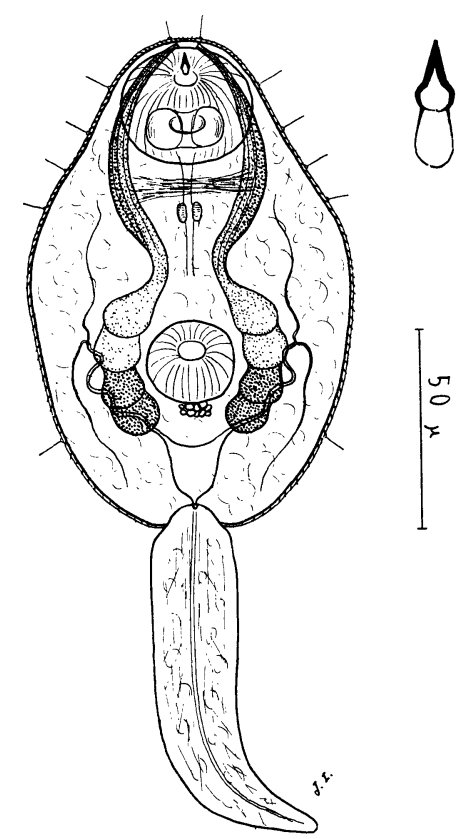

Fig. 10. Cercaria siamensis $\mathrm{n}$. $\mathrm{sp}$.

11. Cercaria setsu n. sp.

Host: Digoniostoma funiculata Walker.

Locality: Mahasarakhan, Thailand.

Specific diagnosis: An ophthalmoxiphidiocercaria being provided with a fin fold on the tail. A body, measuring $297 \mu$ by $172 \mu$, is ellipsoidal in shape. The body surface has no spine but is provided with five pairs of sensory hairs. A well developed oral sucker, measuring $72 \mu$ in diameter, is slightly larger than the ventral sucker, which is measured $64 \mu$ in diameter and is located at a little behind the middle of the body. A small conical stylet is situated at the anterior margin of the oral sucker. A pharynx 
of $18 \times 20 \mu$ in size attaches immediately the posterior margin of the oral sucker without the prepharynx, and is followed by a short esophagus which is divided into two long caeca reaching the posterior end of the body. On both sides of the esophagus are one pair of eye spots, each of which has a lens on its anterior side. Eight or ten pairs of coarsely granulated penetrating gland cells are recognized on both lateral sides of the ventral sucker. Their ducts separating into two groups run forwards and open on the lateral side of the stylet, respectively. Many pigmented granules are scattered around the ventral sucker. A nervous commissure is across the esophagus and divides

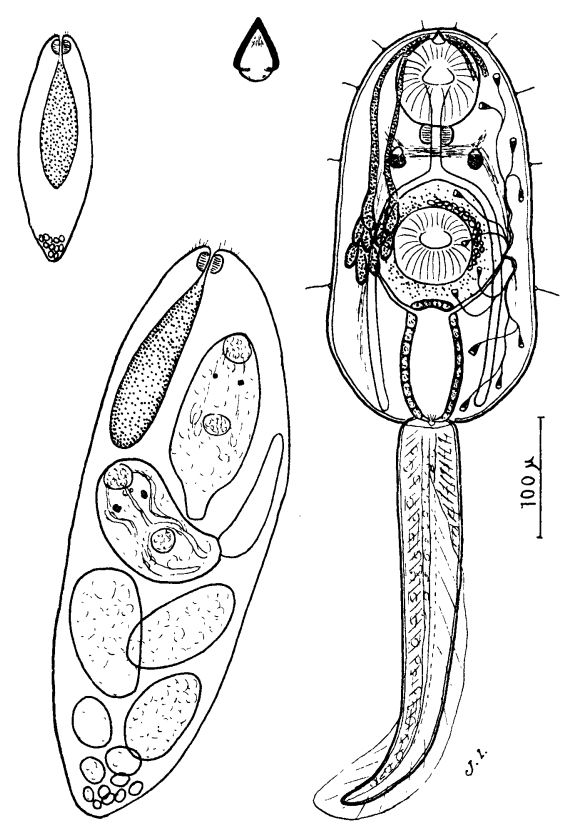

Fig. 11. Cercaria setsu n. sp.

at the place of eye spots into the anterior and the posterior fibers. A well developed large epithelial and cylindrical excretory bladder occupies the posterior space between the ventral sucker and the body end. The excretory system is of a mesostome type and the flame cell formula is represented by $2[(2+2+2)+(2+2+2)]=24$. A small excretory pore is observed at the posterior extremity of the body. A mass of genital primordium is at the right side of the ventral sucker. The tail is longer than the body, measuring $233-323 \mu$ by $50-54 \mu$. It is provided with no spine but with a large dorso-ventral fin fold.

A redia is a simple ellipsoidal in shape. A pharynx is located at the anterior tip of the body and is followed by a long intestine reaching the middle of the body. Many small sensory hairs are around the mouth opening. A few immature cercariae and germ balls are contained in it.

This cercaria is occasionally found from Digoniostoma funiculata, seven out of 7289 snails being infected with this cercaria. Comparing with the other members of Ophthalmoxiphidiocercariae (Ito, 1952), the general feature is much similar except the 
tail which has a prominent dorso-ventral fin fold as shown in Fig. 11. As this group has been proved, the present cercarid may belong to the member of Allocreadiidae or closely related families. A new name, dedicating to my dear wife, Carcaria setsu is presented to the species.

\section{Cercariaeum magnasoma $\mathrm{n}$. sp.}

Host : Digoniostoma funiculata Walker.

Locality: Udon, Thailand.

Specific diagnosis: A large tailless cercaria. In raw materials, pressed in a cover glass, the body measures $1.1 \mathrm{~mm}$ in length and $0.45 \mathrm{~mm}$ in width. The body surface is covered with many spines directing backwards and being distributed more densely

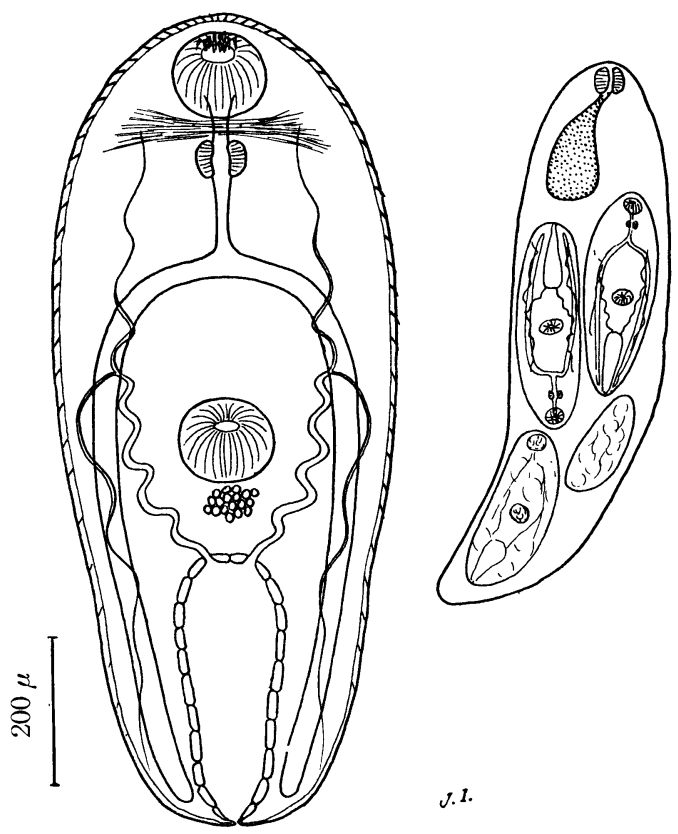

Fig. 12. Cercariaeum magnasoma n. sp.

towards the anterior part. A oral and a ventral sucker are of nearly the same size, measuring $115 \mu$ in diameter. At the mouth opening several spinous hooks are observed. A pharynx measuring $54-72 \mu$, is connected by a short prepharynx and is followed by a $297 \mu$ long esophagus. Intestinal caeca are well defined and reach the posterior end of the body. The nervous commissure is found across the prepharynx. A large cylindrical excretory bladder occupies the posterior part of the body. From its anterior corner, one pair of main collecting tubes starts, running in a zigzag course anteriorly, and divides at the middle of the body into an anterior and a posterior collecting tube, respectively. Flame cell formula could not be determined. A cellular mass of the genital primordium is detected behind the ventral sucker. Rediae are of a large sausage type. A few immature cercariae are contained in it. 
The infection rate of this cercaria was very low. Only one out of a lot of snails was found to be infected with this cercaria. a new name, Cercaria magnasoma n. sp., because of its large size, is given to the present cercaria.

\section{SUMMARY}

During the period from 1960 to 1961,12 species of fresh water snails obtained in Thailand were investigated for cercarial fauna, and four of them were detected to be infected with 12 species of cercariae. They were, cercaria of Schistosoma spindale, Cercaria dorsoptera n. sp. (furcocercous-), cercaria of Echinostoma revolutum, cercaria of Echinochasmus japonicus, cercaria of Notocotylus attenuatus, Cercaria udonensis n. sp. (amphistome-), cercaria of Opisthorchis viverrini, Cercaria digoniostomae n. sp. (microcotyle-), Cercaria krungteb n. sp. (microcotyle-), Cercaria siamensis n. sp. (virgula-), Cercaria setsu n. sp. (ophthalmoxiphidio-), and Cercariaeum magnasoma n. sp. (tailless-). Each of them is described with some discussions. The most abundant species was the cercaria of Schistosoma spindale, which is an important pathogenic blood fluke of the water buffalo. The next common species was the cercaria of Notocotylus attenuatus which may be pathogenic for the domestic duck and the fowl. The cercaria of Opisthorchis viverrini, a famous human liver fluke, was also rather common in Digoniostoma funiculata.

The authors wish to express their sincere thanks to Dr. Tokubei Kuroda who helped us kindly for the identification of snail hosts.

\section{REFERENCES}

ARchibald, R. G. \& Marshall, A. (1931): A technique for the study of cercariae. Trans. Roy. Soc. Trop. Med. \& Hyg., 24, 629-630.

Chatyaporn, V., Koonvisal, L. \& Dharamadhach, A. (1959): The first case of schistosomiasis japonica in Thailand. M. Assoc. Thailand, 42, 438-441.

HARINASUTA, C. \& VAJRAsthiRA, S. (1959): Study on opisthorchiasis in Thailand, 1. The incidence of opisthorchiasis in patients of fifteen hospitals in the Northeast. J. Med. Assoc. Thailand, 42, 584-598.

ITO, J. (1962) : A monograph of Japanese Cercariae. In the Advances of Parasitology in Japan II, Toky, pp. 152 (text in Japanese).

ITo, J. (1952): A description of two xiphidiocercariae, Cercaria okabei Ito, 1949, and Cercaria of Maritrema caridinae (Cercaria takahashii, Yokogawa et Ito, 1949), parasitic in Katayama nosophora in Japan (Trematoda). Jap. M. J., 5, 101-112.

ITO, J. (1959): A contribution to the morphology of cercaria of Notocotylus magniovatus Yamaguti, 1934 (Notocotylidae, Trematoda). Jap. J. M. Sc. \& Biol., 12, 133-137.

ITO, J. \& JATANASEN, S. (1960): A brief survey of parasitic helminth in South Laos and Cambodia with a comparison to the state in Thailand. Jap. J. M. Sc. \& Biol., 14, 257-262.

Ito, J., PAPASARATHORN, T. \& TONGKOOM, B. (1962): An investigation of parasitic helminths of stray dogs in Bangkok. Jap. J. M. Sc. \& Biol., 15, 53-60.

KomiYA, Y. \& TAJIMI, T. (1940): Study on Clonorchis sinensis in the district of Shanghal. 5: The cercaria and metacercaria of Clonorchis sinensis, with special reference to their excretory system. J. Shanghai Sc. Inst., IV, 5, 91.

Liston, W. G. \& SOPARKAR, M. B. (1918): Bilharziosis among animals in India, the lifecycle of Schistosoma spindalis. Indian J. M. Res. 5, 567-569. 
LüHE, M. (1909): Trematoda. In die Susswasserfauna Deutschlands, Heft 17, pp. 217 (text in Germany).

SAdUN, E. H. \& MAIPHOOM, C. (1953): Studies on the epidemiology of the human intestinal fluke, Fasciolopsis buski (Lankaster) in Central Thailand. Am. J. Trop. Med. \& Hyg., 2, 1070-1084.

Sewell, R. B. S. (1922): Cercariae Indicae. Indian J. M. Res., 10, Suppl. No., pp. 370.

SOPARKAR, M. B. (1921): The cercaria of Schistosoma spindalis (Montgomery). Indian J. M. Res., 9, 1-21.

SzIDAT, L. (1936): Uber die Entwicklungsgeschichte und den ersten Zwischenwirt von Paramphistomum cervi Zeder, 1790, aus dem Magen van Wiederkäuern. Zeitschr. f. Parasitenk., 9, 1-19.

Vajrasthira, S., Harinasuta, C. \& MaiphoOM, C. (1958) : Paragonimiasis in Thailand, two years investigation and control. J. M. Assoc. Thailand, 41, 387-405.

VAjRasthira, S., Harinasuta, C. \& KomiYA, Y. (1961): The morphology of the metacercaria of Opisthorchis viverrini, with special reference to the excretory system. Ann. Trop. Med. \& Parasitol., 55, 413-418.

WALL, L. D. (1941) : Life history of Spirorchis elephantis (Cort, 1917); a new blood fluke from Chrysemys picta. Am. Midl. Nat., 25, 402-412.

WALL, L. D. (1941): Spirorchis parvus (Stunkard, 1923), its life history and the development of its excretory system (Trematode: Spirorchidae). Trans. Am. Micr. Soc., 60, 221-260.

WESENBERG-LUND, C. (1934): Contributions to the development of the trematode digenea. Part II. The biology of the fresh water cercariae in Danish fresh waters. D. Kgl. Dansk. Vidensk. Selsk. Skrifter, Naturw. Math. Afd., Raekke, 9; pp. 5, 223.

YAMAGUTI, S. (1938): Zur Entwicklungsgeschichte von Notocotylus attenuatus (Rud., 1809) und N. magniovatus Yamaguti, 1934. Zeitschr. f. Parasitenk., 10, 288-292.

YAMAgUti, S. (1951) : Zur Entwicklungsgeschichte von Echinochasmus japonicus Tanabe, 1926, mit besonderer Berücksichtigung der Struktur der Cercaria. Ard. Med. Fak. Okayama, 7, 338-342.

YAMAGUTJ, S. (1958) : Systema Helminthum. Vol. I. The digenetic trematodes of vertebrates, Part 1. pp. 979. Interscience Publishers.

YokogawA, M. (1962): Assignment Report on Bilharziasis survey (The Mekong River Area). WHO Project: Thailand 61, SEA/Bilharz 5, Restricted panphlet, pp. 9. 


\section{Explanation of Plates}

Plate-fig. 1. Viviparus (Taia) ingallsiana (Lea)

Plate-fig. 2. Viviparus filosus (Reeve) (=lineolatus Reeve?)

Plate-fig. 3. Sinotaia polygramma

Plate-fig. 4. Sinotaia subciliata (Kobert)

Plate-fig. 5. Sinotaia trochoides (Martens)

Plate-fig. 6. Pila (Turbinicola) polita (Deshayes)

Plate-fig. 7. Digoniostoma funiculata Walker

Plate-fig. 8. Wattebledia crosseana (Wattebled)

Plate-fig. 9. Melanoides tuberculatus (Müller)

Plate-fig. 10. Stenomelania brunnescens (Tyron)?

Plate-fig. 11. Clea (Anentome) baudoniana (Mabille et le Mesle)

Plate-fig. 12. Lymnaea (Radix) auricularia rubiginosa Michelin

Plate-fig. 13. Gyraulus convexiusculus (Hutton) (=siamemsis, saigonensis, compressus)

Plate-fig. 14. Hippeutis umbilicalis (Benson) (=schmackeri Clessin)

Plate-fig. 15. Indoplanorbis exustus (Deshayes) (=indicus Benson)

Plate-fig. 16. Allocimma sp.

(Identification of snails were made by Dr. Tokubei Kuroda, in the Biological Laboratory, Kyoto University, Japan) 

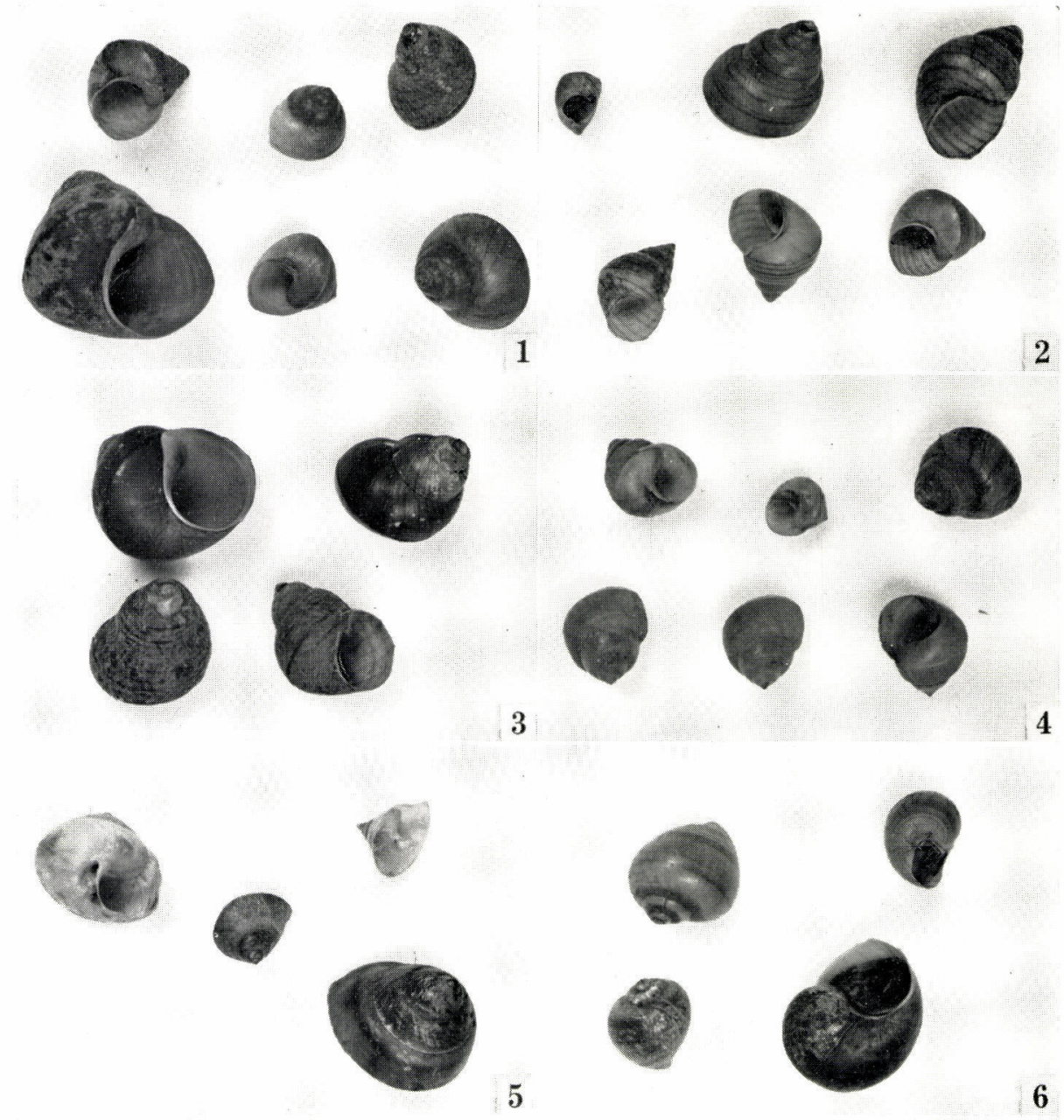

5

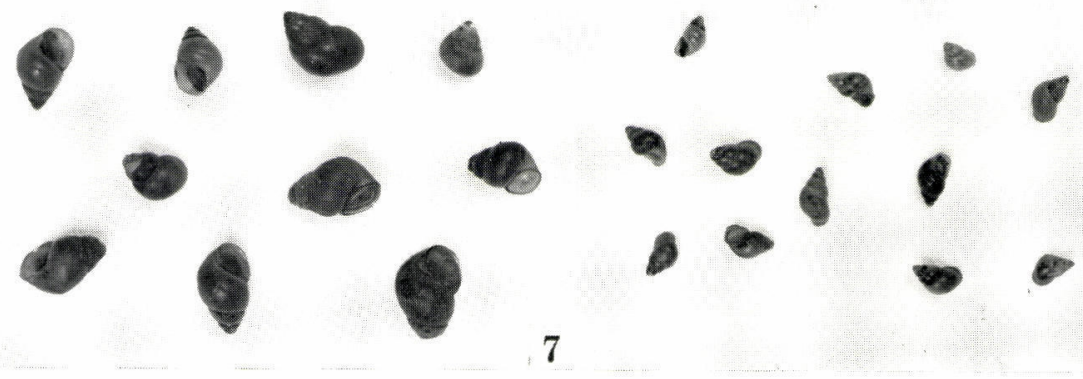



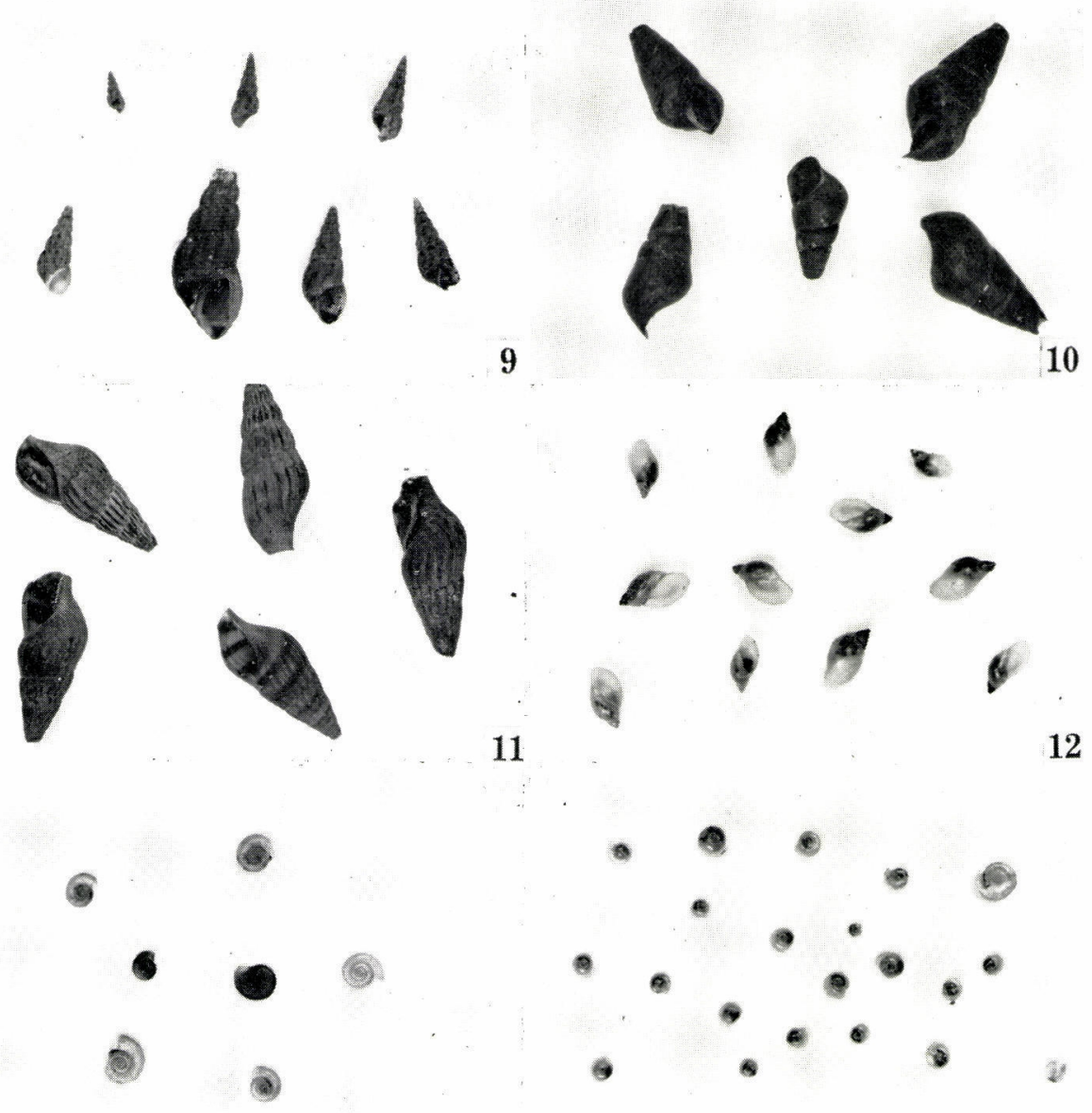

13.

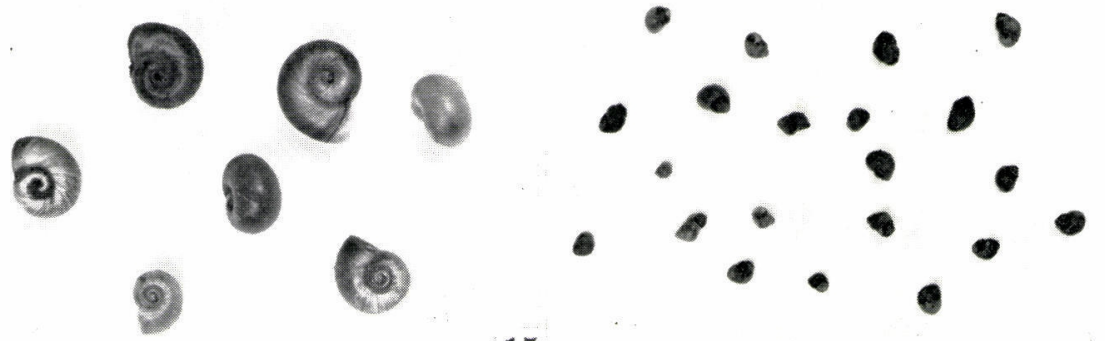

15 